\title{
A clean slate
}

\author{
Nature is pleased to name physicist Steven Chu, Nobel laureate and the US Secretary of Energy, \\ as its Newsmaker of the Year.
}

$\rho$ teven Chu made his name - and earned his Nobel prize - by developing an ingenious laser technique for capturing and studying atoms. He is an extraordinary experimentalist who loves the challenges of the lab. But five years ago, he embraced a much bigger challenge when he took the helm at Lawrence Berkeley National Laboratory in California and dedicated it to clean-energy research. Chu was sworn in as secretary of the US Department of Energy this January, and is now charged with transforming the way the world's largest economy powers itself. That is why Nature has selected Chu as its Newsmaker of the Year (see page 978).

Chu has already had a significant impact. From his position near the top of President Barack Obama's administration, he has helped make the case that the United States must commit to reducing its greenhouse-gas emissions, not only to save the planet but also to ensure that the country will be able to compete with China, India and Europe in the emerging green economy.

And he has started to commit the energy department to doing more high-risk research on clean energy. This is the proper role of governmental research programmes: to develop promising technologies that are too far from the market to draw the support of industry, which has to focus on near-term profits. Nations cannot simply regulate themselves out of the global-warming problem; pledges to cut greenhouse emissions have to be made real by the scientists and engineers who develop cheaper, cleaner and more efficient ways to produce and distribute energy.

Chu has accordingly made it his mission to be a public cheerleader for clean-energy research. As he travels around the United States, he trumpets the need for the best minds of this generation to tackle perhaps the largest problem that society now faces. He has already recruited some top scientists to leave their chosen fields of

research and — just as he did — focus on the energy issue.

Such commitment to public service is a long and honourable tradition among scientists. Thus, Nature's selection of Chu as Newsmaker is also a tribute to the legions of scientists around the world who step away from research, sometimes for life, to tackle the larger problems of society.

There have been times when Chu has struggled during his first year of tenure. Scientists who take leading roles in government are often selected because they, like $\mathrm{Chu}$, are outstanding researchers. But the skills that matter most in a laboratory

"Steven Chu has made it his mission to be a public cheerleader for clean-energy research." are not enough to ensure success in the arena of public policy and politics, where building consensus and finding acceptable compromises are key. As Chu is learning, researchers entering government need to adapt and learn from political leaders.

At the same time, scientists can help politicians to think more scientifically - encouraging them to examine the results of research carefully rather than just follow ideology and political expediency. Chu has taken it upon himself to meet with legislators, particularly those who do not believe that global warming is a problem. He walks them through the science of climate change and the consequences of ignoring it, all with the aim of helping to win passage of a climate bill that will clean up the US energy sector.

Although it would be naive to think that one scientist can move politicians with long-standing opposition to climate legislation, Chu's efforts may help tilt the balance towards the passage of a bill and the eventual ratification of an international climate treaty. Those who stand on the side of logic and data should vigorously support his efforts.

The accord provides a framework for capturing the national

\section{After Copenhagen}

\section{The agreement reached last week lends fresh urgency to challenges in science and communication.}

t is easy to feel disappointed by the accord brokered last week by US President Barack Obama at the United Nations Framework Convention on Climate Change in Copenhagen. The document's broad outlines do not constitute a treaty, nor is it even clear whether it should technically be called a global agreement. Crafted principally by a handful of nations - the United States, China, India, Brazil and South Africa - the accord was presented as a take-it-or-leave-it fait accompli to representatives of the nearly 200 other nations in attendance, few of whom had been consulted. The resulting protests nearly led to the convention's collapse (see page 966). climate commitments already on record, but has no mechanism to enforce them. Nor does it offer any global emissions targets. Even if fully implemented, the accord would allow greenhouse-gas emissions to continue rising beyond 2020, and would put the world on a course towards a warming of nearly $4^{\circ} \mathrm{C}$ by 2100 . It would not halt the acidification of the world's oceans or the melting of its ice. It is so weak that many critics worry that it will actually undermine progress by failing to send a clear signal to markets, investors and governments about the need to reduce greenhouse-gas emissions.

Nonetheless, for the first time, all of the world's largest greenhousegas emitters have signed up to a framework for cooperation on the biggest challenge of our time. For all of its shortcomings, the accord is an important step forwards.

In many ways, the accord represents a snapshot of humanity at a crucial juncture in history. Tensions between rich and poor, north and 